\title{
Duodenal ulcer bleeding led to the first diagnosis of testicular cancer
}

\author{
Thanita Thongtan 지, ${ }^{1}$ Anasua Deb 지, ${ }^{1}$ Lukman Tijani, ${ }^{2}$ Vaness Costilla ${ }^{3}$
}

${ }^{1}$ Internal Medicine, Texas Tech University Health Sciences Center, Lubbock, Texas, USA ${ }^{2}$ Haematology Oncology, Texas Tech University Health Sciences Center, Lubbock, Texas, USA

${ }^{3}$ Gastroenterology, University Medical Center, Lubbock, Texas, USA

\section{Correspondence to Dr Anasua Deb: anasua.deb@gmail.com}

Accepted 4 October 2021

\section{DESCRIPTION}

Worldwide, testicular cancer contributes to $1 \%-2 \%$ of all cancers in men ${ }^{1}$ and is also the most common malignancy in young adult men. ${ }^{2}$ Review of the Surveillance, Epidemiology, and End Results programme database from 1975 to 2015 revealed that in the USA, the incidence of testicular cancer has been increasing. ${ }^{3}$ Germ cell tumour (GCT) is the most common type, accounting for $95 \%$ of testicular cancer cases. ${ }^{4}$ Seminomas account for $60.2 \%$ of GCT and have a varied initial presentation. ${ }^{5}$ Gastrointestinal (GI) presentation of GCT is unusual as they rarely metastasise to the GI tract. ${ }^{6}$ Less than $5 \%$ of all testicular GCT metastasise to the GI tract, whereas the incidence of GI metastasis for seminomas is less than $1 \% .^{7}$ Upper GI tumour bleeding that leads to the first diagnosis of cancer accounts for $2.4 \%$ of all acute upper GI bleeding cases. ${ }^{8}$ We report a case of a male patient who presented with acute upper GI bleeding caused by a duodenal lesion invaded by retroperitoneal metastasis from a testicular GCT.

A 31-year-old man with chronic low back pain who had been taking naproxen for a long time presented with melena and generalised weakness for 2 weeks and a 20-pound weight loss in 1 month. The haemoglobin level was $50 \mathrm{~g} / \mathrm{L}$, and the abdominal examination was unremarkable. Esophagogastroduodenoscopy revealed a non-bleeding cratered duodenal ulcer with pigmented material measuring $20 \mathrm{~mm}$ in the second portion of the duodenum (figure 1). To rule out duodenal perforation, contrastenhanced CT was performed, which revealed a $5.8 \times 5 \mathrm{~cm}$ midline retroperitoneal soft tissue mass that displaced the third portion of the duodenum anteriorly (figure 2). Both the duodenal ulcer biopsy

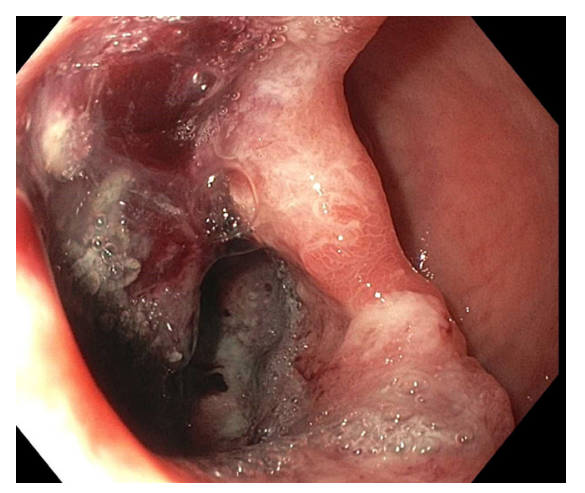

Figure 1 Endoscopic view of a non-bleeding cratered duodenal ulcer with pigmented material in the second portion of the duodenum.

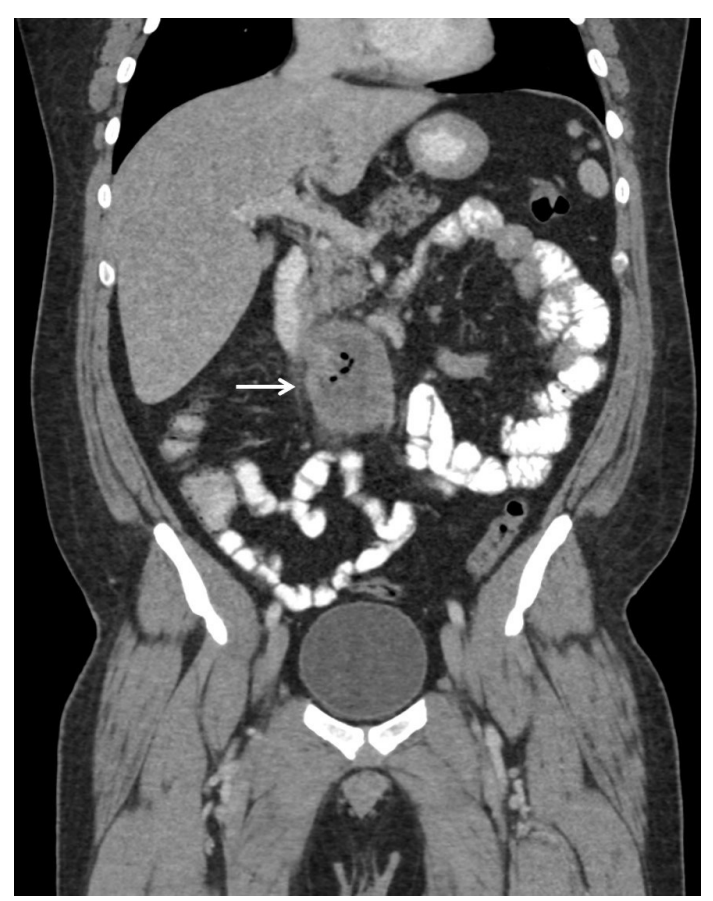

Figure 2 Contrast-enhanced CT revealed a midline retroperitoneal soft tissue mass that displaced the third portion of the duodenum anteriorly (arrow).

and the retroperitoneal mass biopsy revealed embryonal carcinoma (figure 3A). Testicular carcinoma was suspected as the primary source even though the patient had no testicular complaints. Both testicles were soft and normal in size. At the base of the right testicle, there was mild irregular notching. A testicular ultrasound showed that both testes were normal in size and that the right testis had multiple hypodense lesions (figure 4, arrow). The patient underwent right inguinal orchiectomy for diagnosis of staging. The pathological findings of the right testicle were confirmed to be seminoma (figure $3 \mathrm{~B}$ ).
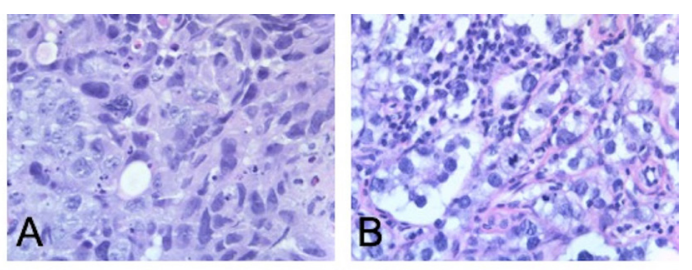

Figure 3 (A) Duodenal ulcer biopsy and the retroperitoneal mass biopsy revealed large highly pleomorphic tumour cells of embryonal carcinoma. (B) Right testicle excisional biopsy revealed seminoma.) Right testicle excisional biopsy revealed seminoma. 


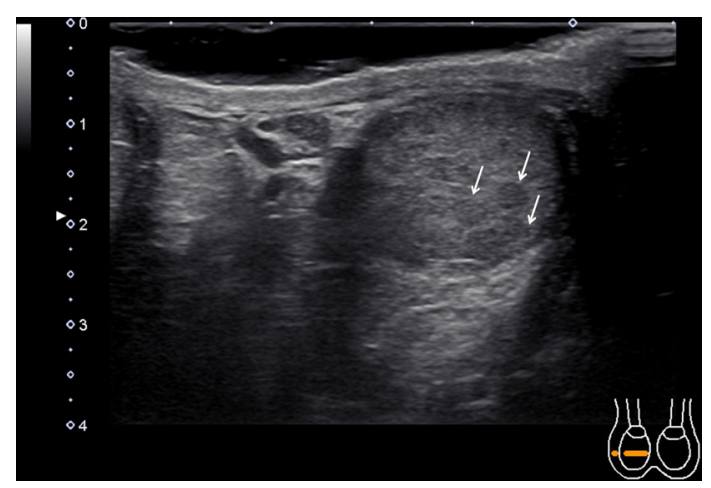

Figure 4 Right testicular ultrasound multiple hypodense lesions (arrow) despite normal size.

The patient was diagnosed with stage IIC right testicular GCT (cT2N3M0S1) and was treated with four cycles of bleomycin, etoposide and cisplatin chemotherapy. The patient is in remission at a 2-year follow-up.

\section{Learning points}

- Patients with testicular cancer may present with gastrointestinal bleeding if the retroperitoneal lymph node metastasis is large enough to extend to the gastrointestinal tract.

- Clinicians should consider a testicular examination in young male patients who present with gastrointestinal bleeding despite no testicular complaint.
Contributors TT was involved in drafting and revising the manuscript and in obtaining patient consent. AD was involved in drafting and revising the manuscript. LT was involved in patient care. LT and VC were involved in supervising and revising the manuscript. All authors have approved the final draft submitted.

Funding The authors have not declared a specific grant for this research from any funding agency in the public, commercial or not-for-profit sectors.

Competing interests None declared.

Patient consent for publication Consent obtained directly from patient(s)

Provenance and peer review Not commissioned; externally peer reviewed.

\section{ORCID iDs}

Thanita Thongtan http://orcid.org/0000-0002-0729-2451

Anasua Deb http://orcid.org/0000-0002-1049-5882

\section{REFERENCES}

1 Park JS, Kim J, Elghiaty A, et al. Recent global trends in testicular cancer incidence and mortality. Medicine 2018;97:e12390.

2 Li Y, Lu Q, Wang Y, et al. Racial differences in testicular cancer in the United States: descriptive epidemiology. BMC Cancer 2020;20:284.

3 Reese SW, Tully KH, Nabi J, et al. Temporal trends in the incidence of testicular cancer in the United States over the past four decades. Eur Urol Oncol 2020;5258 8-9311:30089-4.

4 Chung P, Warde P. Testicular cancer: germ cell tumours. BMJ Clin Evid 2016;2016:1807.

5 Dieckmann K-P, Richter-Simonsen H, Kulejewski M, et al. Testicular germ-cell tumours: a descriptive analysis of clinical characteristics at first presentation. Urol Int 2018;100:409-19.

6 Savides TJ, Jensen DM, Cohen J, et al. Severe upper gastrointestinal tumor bleeding: endoscopic findings, treatment, and outcome. Endoscopy 1996;28:244-8.

7 Senadhi V, Dutta S. Testicular seminoma metastasis to the gastrointestinal tract and the necessity of surgery. J Gastrointest Cancer 2012;43:499-501.

8 Shogbesan 0, Abdulkareem A, Jehangir A, et al. Gastrointestinal involvement of testicular germ cell tumor: a case report and literature review. Case Rep Gastrointest Med 2017;2017:4789259

Copyright 2021 BMJ Publishing Group. All rights reserved. For permission to reuse any of this content visit https://www.bmj.com/company/products-services/rights-and-licensing/permissions/ BMJ Case Report Fellows may re-use this article for personal use and teaching without any further permission.

Become a Fellow of BMJ Case Reports today and you can:

- Submit as many cases as you like

- Enjoy fast sympathetic peer review and rapid publication of accepted articles

- Access all the published articles

- Re-use any of the published material for personal use and teaching without further permission

\section{Customer Service}

If you have any further queries about your subscription, please contact our customer services team on +44 (0) 2071111105 or via email at support@bmj.com.

Visit casereports.bmj.com for more articles like this and to become a Fellow 